chapters on economics follow in which L. H. Goulder and D. Kennedy review alternative approaches to valuation and R. Costanza and C. Folke discuss how valuations are complicated by context, including the many different goals of societies.

The next section contains five excellent overviews of feedback between life and climate (S. E. Alexander, S. H. Schneider and K. Laggerquist); biodiversity and ecosystem function (D. Tilman); and the services provided by soils (G. C. Daily, P. A. Matson and P. M. Vitousek), pollinators (G. P. Nabhan and S. L. Buchmann) and natural enemies contributing to the control of agricultural pests (R. L. Naylor and P. R. Ehrlich).

All these chapters succeed in orienting general readers to the topic, yet also provide comprehensive up-to-date summaries of recent research and guides to the relevant literature. The authors use sometimes ingenious methods of estimating absolute and marginal values of particular ecosystem services at regional and global scales.

The third section reviews services supplied by important biomes: marine (C. $\mathrm{H}$. Peterson and J. Lubchenco); fresh water (S. Postel and S. Carpenter); forest (N. Myers); and grassland (O. E. Sala and J. M. Paruelo).

Postel and Carpenter point out that while fresh water has no substitute, its value under certain limiting conditions can be estimated from the replacement costs of using desalinized sea water. This practice is currently largely confined to the Persian Gulf where nations convert oil wealth to water at a cost of \$1-\$2 per cubic metre. In the less water-starved and less wealthy arid western United States, their analysis shows that today's marginal value of water for recreation, fisheries and other in-stream uses often exceeds the marginal value of water diverted for agriculture, so that "if the water market were freer, fewer diversions would be economically justified".

The next section contains miscellaneous case histories including a chapter on marine resource extraction (L. Kaufman and P. Dayton); a survey of the value of global biodiversity (N. Myers); tradeoffs between environmental conservation and development in a community in the Rocky Mountains in the United States (A. Wilcox and J. Harte); a discussion of the uses of natural and reconstructed wetlands (K. C. Ewel); and an analysis by R. M. Cowling, R. Costanza and S. I. Higgins of whether beating back the invasive exotic vegetation threatening the fynbos (a hard-leafed, fireprone shrubland) ecosystem of South Africa can be economically justified (it can).

A particularly fascinating chapter in this section by K. S. Bawa and M. Gadgil reviews ecosystem services used by people in subsistence economies, and discusses the feasibility of enlisting these people in efforts to preserve their local biodiversity. Follow- ing R. F. Dasmann, Bawa and Gadgil distinguish "ecosystem people" who rely on local ecosystems for most of their resources from "biosphere people", such as urbanites whose resources are drawn from much of the planet. Environmental degradation caused by resource extraction is generally invisible to biosphere people, but has immediate and sometimes tragic consequences for ecosystem people, such as the ecological refugees displaced by dams, deforestation or anthropogenic desertification.

Bawa and Gadgil point out that ecosystem people have conserved biodiversity and natural resources "when these serve the longterm interests of a small, well-knit human group". They offer practical ideas for fostering social and economic conditions that would permit these people to remain stewards and beneficiaries of their lands.

Yvonne Baskin's The Work of Nature is a well-written popular account of the recent investigations of community ecologists and ecosystem scientists whose findings are relevant to ecosystem services. With many vivid examples, Baskin reviews research that illustrates how species interactions influence ecosystems, emphasizing that some species that appear unnecessary or 'redundant' today may prove crucial tomorrow as conditions or circumstances change.

Her chapters reviewing keystone species and community interactions are gems, as is her lucid treatment of the adverse impact of invading species on the health of forests, fisheries or humans. Later she discusses ecosystem-level investigations of how soil and vegetation interact with climate and hydrology. She then reviews the fascinating studies of $\mathrm{N}$. Owen-Smith, P. Martin, and S. Zimov, T. and M. Chapin and their colleagues who, in Africa, North America and Beringia respectively, have built cases for continental scale impacts of prehistoric humans who eliminated megaherbivores.

In her chapter "Do we still need Nature?" Baskin discusses the failure of the $\$ 150$ million Biosphere II project, in which the atmosphere suffered from overproduction of carbon dioxide and underproduction of oxygen. She relates several other cautionary tales of failed engineering fixes that attempted to replace free natural services lost as ecosystems degraded.

With specific case studies such as the pollution of estuaries by cage culture of salmon, she illustrates problems that arise when local owners and beneficiaries are not paying for the loss of services from ecosystems that they overwhelm and degrade. As Daniel Schneider has pointed out in his work on the conversion of the Illinois River floodplain to cornfields, in contrast to Hardin's "tragedy of the commons" model, the most severe environmental degradation can follow the privatization of formerly public lands.

Both books are 'must reads' for teachers, students, scientists and citizens at all levels of expertise. The valuation of nature should be considered and widely debated by all concerned with humanity's future.

Pricing nature may disturb and depress 'green' readers. They should keep reading, for these authors are not among those "for whom every value can be made monetary", to use Naylor and Ehrlich's phrase. The authors do not believe that nature's only purpose is to comfort, support or amuse humans. They have simply confronted the reality that, in the world as it is today, putting a minimum monetary estimate on nature's services is the only way to slow, and hopefully eventually to stop, the loss of its crucial life-support functions.

Mary Power is in the Department of Integrative Biology, University of California at Berkeley, Berkeley, California 94720, USA.

\section{Science in the service of the Raj}

\section{The Science of Empire: Scientific Knowledge, Civilization, and Colonial Rule in India \\ by Zaheer Baber \\ State University of New York Press: 1996. \\ Pp. 298. \$71.50, $\mathfrak{E} 55.75$ (hbk); \$23.95, $\mathfrak{E} 18.75$ (pbk) \\ Mapping an Empire: The Geographical Construction of British India, 1765-1843} by Matthew H. Edney

University of Chicago Press: 1997. Pp. 436.

$\$ 35, \mathfrak{2} 27.95$

\section{Ehsan Masood}

Step onto any main thoroughfare in New Delhi, Mumbai (Bombay), Lahore or Karachi, and you'll find that the traffic drives on the left, just as it does in Britain. Step into an office, and you'll be offered tea with milk and sugar served by uniformed men still quaintly referred to as 'peons', the name given to the native servants of the Raj.

The imperial crown fell with the creation of India and Pakistan on 14 and 15 August 1947. But, by mostaccounts, the shadow of the Union Jack, the gaberdine suit and the khaki helmet still looms large.

English remains the language of business and education. Application forms are completed 'in triplicate. 'Oxford' is a name used by garment manufacturers and nursery schools. The school leaving examination is still called a 'matriculation'. A university student with high enough grades will graduate with 'honours'. And, should he want to become a scientist, he may end up working for the Council for Scientific and Industrial Research.

Two books on the role of science in the spread of empire published in time for the fiftieth anniversary of independence confirm 
that the stamp of the crown is too well defined to be erased by the ritual renaming of streets and towns, the compulsory wearing of nonWestern attire, or crude attempts to abolish English as the main language of education.

The books by Zaheer Baber and Matthew H. Edney are part of the already substantial literature on empire to emerge from the colonial archives at, among others, the British Library Oriental and India Office Collections in London.

Some historians do not consider sifting through such records as 'real' historical research. They argue that such an exercise is not so much research as stamp-collecting, as the material is already in one place, and properly indexed. They also believe that such investigations reflect only part of a story as they rely almost exclusively on 'secondary' source materials; indeed, from a single source - the colonial power. They also argue that the conclusions drawn from such studies are hardly new, as each survey repeats previous findings that colonial powers exploited those in their control for economic and territorial gains.

There is merit in such an argument. But it would be unfair to dismiss these books as unwanted additions to the overcrowded market for 'secondary-level' studies on the British Empire. For that is not their aim.

The books' novelty lies not in their conclusions on the exploitative nature of empire. Rather, they provide a glimpse of the fruits that lie ahead if historians of science, and sociologists of science, start to acknowledge each others' existence. The virtual absence of people in the field of science studies from last month's international congress of historians of science in Liège, Belgium, suggests, for example, that such an accommodation has some way to go.

Why should this be the case? Until now, many historians of science have been content to piece together specific examples from research in the past, without necessarily recounting the prevailing social, cultural, religious and political forces that may have shaped the nature of that science. This irritates sociologists of science who argue that digging out the minutiae of science in India, China, the Middle East or the Ottoman Empire is meaningless unless understood in the prevailing social context. But sociologists, too, have so far shown little vision in this area, and seem to prefer to go into combat with natural scientists about questions on the nature of science.

It is, therefore, heartening to see Baber, a sociologist at the National University of Singapore, break free from the 'Science Wars' by attempting to analyse the politics of science in colonial India in The Science of Empire. In the second book, Mapping an Empire, Edney, associate professor of geography and anthropology at the University of Southern Maine, performs a similar exercise on one specific area of science in British India: cartography.

What Baber and Edney have done is effec-

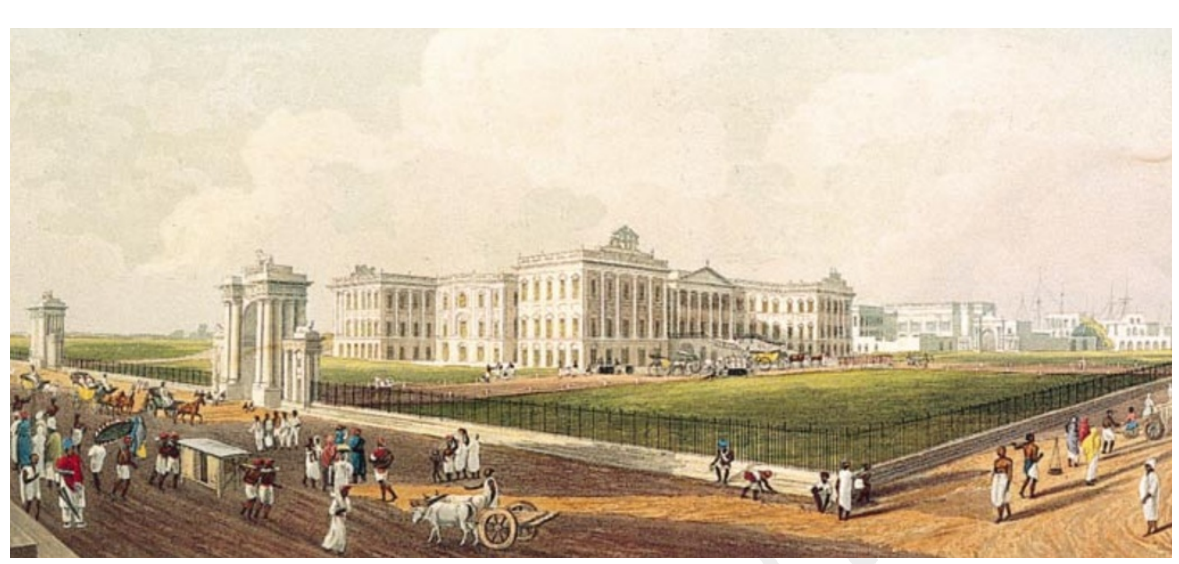

Government House, Calcutta, built in 1798-1803 for Governor-General Lord Wellesley, whose recall was partly due to the extravagant outlay.

tively to reconstruct the history, debates and politics of science in colonial India. The strengths of both studies are the detailed pictures that emerge from the background to the setting up of major institutions of science.

Baber and Edney demonstrate that science in colonial India was no abstract pursuit for gentlemen of leisure that happened by accident. Rather it was a multi-purpose tool with clear applications in mind. These included providing scientific advice to government, assisting in the process of wealth creation, and re-educating the 'natives' in the virtues of science and reason, in place of their own 'irrational' beliefs and practices.

It is fascinating to read how many of the debates described are still as relevant today as they were two centuries ago.

While Edney concentrates on institutions concerned with cartography, Baber takes a broader look at, among others, the Royal Asiatic Society - modelled on the Royal Society of London - the Royal Botanic Garden of Calcutta, and the Board of Scientific Advice, an expert advisory committee that coordinated research across India. The authors show that each institution emerged for a specific reason, which invariably revolved around the idea of easing the process of colonial administration, rather than merely pursuing good science.

India officially became a British colony in 1857. But it was a colony in all but name up to a century earlier while being administered by the powerful East India Company. The company had first arrived in the early 1600s as a trading company. It quickly prospered, and became involved in local politics. In 1757 it lent its large private army to a rebellion against the ruler of Bengal, and found itself in control of India's most prosperous province. Further battles followed, and the company - a confusing name for what was effectively a powerful military force - acquired more territories. The British government, not oblivious to these developments, increased its control over the company's affairs in 1813, before taking over in 1857.

The growth of the company's influence across India generated the need for accurate geographical information. And one of the earliest applications of science in India was in attempts to survey the vast new territories falling under the company's jurisdiction.

Edney describes in detail how the mapping of India began in 1765 after the fall of Bengal, and how the surveys were supported by the East India Company as a means of establishing the boundaries of empire. "To govern territories," says Edney, "one must know them."

But the company was always a reluctant investor in research, particularly research that had no clear application. And, despite the rhetoric about introducing 'scientific method' to India, Edney reveals that the surveying was a disorganized affair that lacked a consistent method until as late as the 1830s, and was completed only after a series of technological fixes. Baber confirms the company's early hesitancy in funding science and shows that officials drew on the advice of research scientists only when problems in governance began to mount.

A series of devastating famines in Bengal in the second half of the eighteenth century was one such problem in which science was asked to play a major role. The famines began just after 1757, and led to massive crop failures, starvation and flight from the land. Faced with the prospect of a financial crisis from falling agricultural revenues, the company's directors welcomed a proposal in 1787 from an army officer and amateur botanist to set up the Royal Botanic Garden of Calcutta, not as a centre for classifying rare plants, but as a money-spinning venture.

The idea was cleverly sold to the directors of the East India Company as an experimental station to cultivate commodities with high revenue potential, such as spices, herbs, dyes, drugs, coffee and tea, and to replace revenues lost from failed crops, such as rice and cotton. This can with hindsight be considered an early example of technology foresight and, within four years of the setting up of the Calcutta garden, similar centres had sprung up in Madras and Bombay.

Baber points out that the network of gar- 
dens was not set up to tackle the famines. These would continue for more than a century, killing hundreds of thousands, and turning one-third of Bengal into a wasteland, before research was brought to bear on the problem.

Science returned to the scene of the famines with the setting up in 1880 of a 'scientific commission' of experts. The commission concluded that the problem would be better understood if each province contained a dedicated agricultural research department, and India's existing network of agricultural research centres was born. But Baber says that the scientists did not have it all their own way. Recommendations that could harm Britain's interests, such as one to reduce dependency on agriculture by developing industry in India, were ignored.

Meanwhile, the famines continued, wiping out all livestock and leaving 6 million people destitute in 1900. A new viceroy, George Curzon, was more determined than ever to apply science and technology to alleviating famine. Agricultural research was strengthened further. Pay and conditions for scientists were improved. And in 1902, Curzon took the additional step of setting up a Board of Scientific Advice to advise the government and coordinate research relating to the economy and agriculture.

This board, says Baber, "bore a striking resemblance to the 'Scientific Advisory Council' proposed for Britain three decades earlier by Alexander Strange, and Norman Lockyer". Lockyer, the first editor of Nature, was excited about the project, and covered the founding of the board in the journal $(67,568 ; 1903)$, as did some newspapers.

But the board did little to alleviate the famines, which appear to have ceased a few years before the end of empire. Baber believes that the colonial administrators knew full well that the famines had begun more than a century earlier as a result of an onerous tax burden, coupled to the neglect of irrigation systems. Science, deliberately or otherwise, proved a useful diversionary tactic.

In addition, the board's usefulness as an analogue for a similar committee in Britain remains debatable, given its inappropriately bureaucratic nature. The board's annual reports were communicated through the Secretary of State for India to the Royal Society. The society would then consult another advisory committee set up to liaise between the administrations in Britain and India. This committee would report back to the colonial office in India, providing any appropriate advice.

Both books contain many other examples of how institutions of science emerged during the colonial period in response to the political and economic problems of the day. Baber also attempts to provide information on science in ancient and mediaeval India. But, lacking access to good primary source material, his coverage contains little of the social and political context that so successfully illuminates his later chapters.

This, in a sense, brings us back to where we started. An understanding of the social context of science in different societies requires a mastery of history, science and language. The historiography of science in European colonial times is relatively easy to research, as most of the source material is well documented. An additional bonus for researchers from Europe and the United States is that it is in English. The development of science in non-Western empires, though, is more difficult to research.

Step back to before the sixteenth century, and the picture becomes hazy, as source material has yet to be properly catalogued. Some sociologists increasingly appear to want to pursue this research. But they lack the prerequisite training in language and history. On the other hand, the handful of those who have such skills - the professional historians of science - consider the pursuit of context to be a diversion from their job as historians. A meeting of minds is on few agendas.

This is unfortunate, as concerted cohabitation may one day lead to an assault on the one question that both groups are keen to answer: why did the scientific revolution happen in the West? Until this marriage takes place, we may never know.

Ehsan Masood is a science writer on Nature and is writing a book on the politics of science in Pakistan.

\section{A private function}

Why is Sex Fun? The Evolution of
Human Sexuality
by Jared Diamond
BasicBooks/Weidenfeld and Nicolson: 1997.
Pp. $168 . \$ 20, £ 11.99$
Alison Jolly

"Recreational sex and menopause were as important for our development of fire, language, art and writing as were our upright posture and large brains." Jared Diamond sets up a major claim at the start of Why is Sex Fun?. He then discusses not only recreational sex, but the evolutionary reasons why men philander more than women, whom it pays to desert first, why men don't breastfeed even though they could (and if in vitro fertilization keeps producing twins, perhaps will yet do so), and many other intriguing thoughts, ending with the overgrown human penis.

The author assumes no prior knowledge. Little of the story will surprise readers of the literature, or of Diamond's wonderful Third Chimpanzee (HarperCollins, 1992). But it is beautifully told, with male breast-feeding introducing a primer on embryonic sex differentiation, menopause one on life history strategy, and concealed ovulation the principle that evolution works on what is there.

Concealed ovulation and sex for fun may well have changed over time from the 'manyfathers' function, with troop males bamboozled into tolerating every infant as their own, to the opposite 'daddy-at-home' function of tribal males' paternal confidence, directed child-care and frequent sex with a loving maybe even monogamous - wife.

Diamond's recurrent ploy is to present his case, then add, "By now you are probably objecting that...". This lets him deal with counter-arguments while flattering the reader, who actually had only a dim feeling that there must be a catch somewhere. This book is simply written, but not simply thought out - it is a good book to leave around, half-hidden, to tempt teenage offspring to become biologists.

But what of Diamond's first big claim? He makes a clear case that monogamy within a community group, sex in private, menopause and our high parental investment are unique among our close primate kin. He does not quite sum up: there should be two pages more to pull the scenario together. Does he think that our unique sexual behaviour is itself what needs explaining, or is it an explanation?

Does he see a bipedal male australopithecine striding along like one of his New Guinea trackers, head high and hands free for defence against the genocidal males of the next group? And the female finding safety and paternal care more and more from a single mate as she evolves into early Homo, and focuses her extended sexual attractiveness from the many to the few, in private?

If this mating system accompanied the earliest expansion of the hominid brain, it would have provided a way for extended parental care to foster the slow growth of big-brained children (a familiar thought), while allowing an almost indefinitely expanded social group, which in turn would have demanded the brainpower of an expanding neocortex.

Diamond adds a factor much less often considered than the needs of children: the value of the old. A toothless crone who still recalls the famine food she ate after the hurricane of 1910 becomes both the tribal university library and their spaceship survival manual. Are longevity and menopause not just the result of bigger brains? Perhaps they evolved simultaneously or were even prerequisites? And how does this accord with Diamond's own preference for a 'big bang' emergence of language, art and religion a mere 30,000 years ago? Perhaps he should now write his missing two-page scenario.

Alison Jolly is in the Department of Ecology and Evolutionary Biology, Princeton University,

Princeton, New Jersey 08544-1003, USA. 